\title{
Kepemilikan Manajerial, Kepemilikan Institusi dan Komisaris Independen Terhadap Nilai Perusahaan Dengan Peran Integrated Reporting Sebagai Pemoderasi
}

\author{
Yudi Wahyudin 1 , Suratno 2 , Suyanto 3 \\ 1,2 Universitas Pancasila, Jakarta, Indonesia \\ ${ }^{3}$ Sekolah Tinggi Ilmu Ekonomi (IPWI) Jakarta, Indonesia
}

\section{INFO ARTIKEL \\ JEL Classification :}

M41, G32

Keywords :

good corporate

governance, managerial

ownership, institusional

ownership, independent

commissioners, integrated

reporting moderate

\begin{abstract}
The purpose of this study is to obtain empirical evidence of the influence of Good Corporate Governance towards Firm Value and after being moderated by the quality of Integrated Reporting. The sample in this study consisted of 95 financial statements of state-owned enterprises (SOEs) listed on the Indonesia Stock Exchange (IDX) in 2014-2018. The analysis technique uses Partial Least Square. The results and findings of the study show that Managerial Ownership and Independent Commissioners do not have affect towards Firm Value, while Institutional Ownership have affect towards Firm Value. Meanwhile, Managerial Ownership and Institutional Ownership do not have affect towards Firm Value after being moderated by Integrated Reporting. Meanwhile Independent Commissioners have a significant effect on Company Value after being moderated by Integrated Reporting.
\end{abstract}

\begin{abstract}
ABSTRAK
Tujuan dalam penelitian ini untuk mendapatkan bukti empiris pengaruh Good Corporate Governance terhadap Nilai Perusahaan dan setelah dimoderasi oleh kualitas Integrated Reporting. Sampel dalam penelitian ini terdiri dari 95 laporan keuangan perusahaan Badan Usaha Milik Negara (BUMN) yang terdaftar di Bursa Efek Indonesia (BEI) pada tahun 2014-2018. Teknik analisis menggunakan Partial Least Square. Hasil dan temuan penelitian menunjukkan bahwa Kepemilikan Manajerial dan Komisaris Independen tidak berpengaruh terhadap Nilai Perusahaan, sedangkan Kepemilikan Institusi berpengaruh terhadap Nilai Perusahaan. Sementara itu, Kepemilikan Manajerial dan Kepemilikan Institusi tidak berpengaruh terhadap Nilai Perusahaan setelah dimoderasi oleh Integrated Reporting. Sedangkan Komisaris Independen berpengaruh signifikan terhadap Nilai Perusahaan setelah dimoderasi oleh Integrated Reporting.
\end{abstract}

\section{Pendahuluan}

Salah satu tujuan perusahaan adalah memberikan jaminan kemakmuran kepada para pemegang saham melalui peningkatan nilai perusahaan agar mereka tertarik untuk melakukan investasi. Seperti yang dinyatakan oleh Ardianto \& Ardini (2018) bahwa "nilai perusahaan yang sangat tinggi dapat meningkatkan kemakmuran pemegang saham, sehingga para pemegang saham akan menginventasikan modalnya kepada perusahaan tersebut". 
Perkembangan nilai perusahaan pada perusahaan BUMN yang terdaftar di Bursa Efek Indonesia selama periode tahun $2014-2018$ dapat dilihat pada gambar berikut ini:

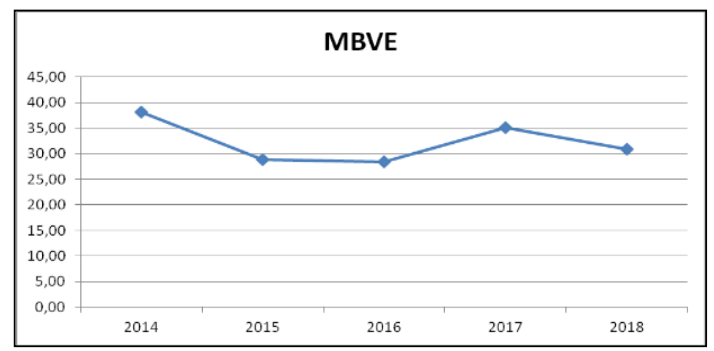

Sumber : Data diolah penulis 2019.

Gambar 1. Perkembangan Nilai Perusahaan BUMN Periode 2014 - 2018

Perkembangan nilai perusahaan BUMN selama periode 2014 sampai dengan 2018 mengalami kecenderungan menurun. Penurunan yang signifikan terjadi pada tahun 2015 dan mengalami penurunan yang tidak terlalu besar pada tahun 2016. Lalu kemudian mengalami pergerakan yang cukup baik pada tahun 2017. Akan tetapi pada tahun 2018 pergerakan nilai perusahan kembali mengalami penurunan.

Salah satu hal yang diharapkan mampu untuk menambah dan memaksimalkan nilai perusahaan adalah implementasi dari good corporate governance. GCG diharapkan mampu mengusahakan keseimbangan antara berbagai kepentingan yang dapat memberikan keuntungan bagi perusahaan secara menyeluruh (Retno \& Priantinah, 2012).

Perkembangan penerapan good corporate governance berdasarkan penilaian yang dilakukan oleh Indonesia Institute of Corporate Directorship 2015 yang disajikan dalam Asean Corporate Governance Scorecard Country Reports and Assessments 2015 from Asian Development Bank (ADB) dapat dilihat pada gambar berikut ini:

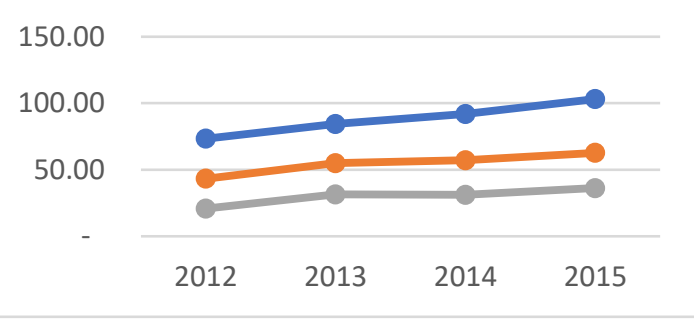

Sumber: Asian Development Bank (ADB), 2017.

Gambar 2. Perkembangan Corporate Governance di Indonesia
Dari grafik di atas dapat di lihat bahwa nilai rata-rata penerapan corporate governance di Indonesia terus mengalami peningkatan selama periode tahun 2012 sampai 2015. Hal ini tidak seiring dengan peningkatan nilai perusahaan yang cenderung tidak konsisten.

Penelitian yang dilakukan oleh Santoso (2017) yang menyatakan bahwa "good corporate governance yang diwakili oleh proksi kepemilikan institusional memiliki pengaruh langsung yang signifikan positif terhadap nilai perusahaan, dan memiliki pengaruh tidak langsung yang signifikan terhadap nilai perusahaan ketika menggunakan kinerja keuangan sebagai variabel intervening”.

Berbeda dengan penelitian yang dilakukan oleh Rahmadani \& Rahayu (2017) yang menyatakan bahwa "good corporate governance tidak berpengaruh terhadap nilai perusahaan". Sedangkan menurut Ardianto \& Ardini (2018) menyatakan bahwa "kepemilikan manajerial tidak berpengaruh terhadap nilai perusahaan dikarenakan kepemilikan saham atas direksi dan komisaris dapat dianggap memperburuk kondisi perusahaan dengan adanya ekspropriasi. Kepemilikan institusional tidak berpengaruh terhadap nilai perusahaan dikarenakan adanya asimetri informasi yang dimiliki oleh manajer sebagai pengelola perusahaan juga institusi sebagai pemegang saham mayoritas kurang optimal. Sedangkan dewan komisaris independen berpengaruh terhadap nilai perusahaan. Hal ini disebabkan komisaris independen ini dapat memaksimalkan kinerja perusahaan yang fungsinya sebagai monitoring yang baik".

\section{Telaah Teori Dan Pengembangan Hipotesis}

\section{Signalling Theory}

Manajemen akan berusaha menginformasikan pencapaian-pencapaian perusahaan selama periode tahun berjalan. Penyampaian informasi mengenai keberhasilan perusahaan kepada pihak eksternal diharapkan akan menjadi sinyal positif bagi perusahaan.

\section{Agency Theory}

(Jensen \& Meckling, 1976) mendefinisikan hubungan keagenan sebagai kontrak dimana satu atau lebih orang (principal(s)) melibatkan orang lain (agent) untuk melakukan beberapa layanan atas nama mereka yang melibatkan 
pendelegasian wewenang pengambilan keputusan kepada agen.

\section{Nilai Perusahaan}

Nilai perusahaan dapat terlihat dari berapa harga yang rela dibayarkan oleh investor untuk memperoleh saham perusahaan. Semakin tinggi harga yang dibayarkan oleh investor, akan meningkatkan nilai sebuah perusahaan.

\section{Good Corporate Governance}

"Good corporate governance merupakan proses struktur pengelolaan bisnis dan urusanurusan perusahaan lainnya dalam rangka meningkatkan kemakmuran korporasi dan akuntabilitas perusahaan dengan tujuan utama mewujudkan nilai pemegang saham yang optimal dalam jangka panjang dengan tetap memperhatikan kepentingan shareholders yang lain" (Ahmar \& Kurniawan, 2007).

\section{Kepemilikan Manajerial}

Keterlibatan manajer dalam kepemilikan saham akan mendorong manajer untuk bertindak secara hati-hati karena mereka akan menanggung konsekuensi atas setiap keputusan yang diambil. Dengan adanya keterlibatan dalam kepemilikan saham, akan meningkatkan motivasi manajer dalam pencapaian kinerja yang optimal.

$\mathrm{H}_{1}$ : Kepemilikan manajerial berpengaruh signifikan terhadap nilai perusahaan

\section{Kepemilikan Institusional}

Kepemilikan institusional merupakan persentase kepemilikan saham oleh investor institusional seperti perusahaan investasi, perbankan, perusahaan asuransi maupun kepemilikan lembaga dan juga perusahaan lain. Kepemilikan institusional dalam perusahaan akan meningkatkan pengawasan terhadap perusahaan. Pengawasan yang efektif dapat mengendalikan perilaku oportunistik manajer. Seperti yang diungkapkan oleh santoso (2017) yang menyatakan bahwa "kepemilikan institusional memiliki pengaruh signifikan positif terhadap nilai perusahaan".

$\mathrm{H}_{2}$ : Kepemilikan institusional berpengaruh signifikan terhadap nilai perusahaan

\section{Komisaris Independen}

Berdasarkan Peraturan Otoritas Jasa Keuangan Nomor 33/POJK.04/2014 tentang Direksi dan Dewan Komisaris Emiten atau
Perusahaan Publik, Komisaris Independen adalah anggota Dewan Komisaris yang berasal dari luar emiten atau perusahaan publik dan memenuhi persyaratan sebagai komisaris independen. Jumlah Komisaris Independen wajib paling sedikit 30\% (tiga puluh persen) dari jumlah seluruh anggota Dewan Komisaris. "Keberadaan dewan komisaris independen dalam perusahaan memberikan pengaruh yang signifikan terhadap nilai perusahaan" seperti yang di ungkapkan oleh Badruddien (2017).

H3: Komisaris independen berpengaruh signifikan terhadap nilai perusahaan

\section{Integrated Reporting}

Definisi Integrated Reporting $<\mathrm{IR}>$ menurut The International Integrated Reporting Committee (IIRC) adalah merupakan laporan terpadu yang mengkomunikasikan secara singkat bagaimana strategi organisasi, tata kelola, kinerja dan prospek, dalam konteks lingkungan eksternalnya, mengarah pada penciptaan nilai dalam jangka pendek, menengah dan jangka panjang (IIRC, 2013).

Integrated Reporting merupakan mekanisme dalam mengkomunikasikan mengenai strategi, tata kelola, kinerja dan prospek yang berkaitan satu dengan lainnya dalam suatu laporan tunggal melalui laporan tahunan (Novaridha, Indrawati, \& L, 2017). Pengungkapan penerapan Good Corporate Governance dalam Integrated Reporting akan meningkatkan minat investor untuk melakukan investasi diperusahaan, yang pada akhirnya akan meningkatkan nilai perusahaan.

$\mathrm{H}_{4}$ : Kepemilikan manajerial berpengaruh signifikan terhadap nilai perusahaan setelah dimoderasi oleh Integrated Reporting

$\mathrm{H}_{5}$ : Kepemilikan institusional berpengaruh signifikan terhadap nilai perusahaan setelah dimoderasi oleh Integrated Reporting

$\mathrm{H}_{6}$ : Komisaris independen berpengaruh signifikan terhadap nilai perusahaan setelah dimoderasi oleh Integrated Reporting

\section{Metode Penelitian}

Penelitian ini di desain untuk menguji pengaruh dari penerapan good corporate governance terhadap nilai perusahaan. Komponen GCG yang digunakan meliputi kepemilikan manajerial, kepemilikan institusi dan komisaris independen. Ketiga komponen tersebut akan dianalisis secara statistik untuk 
menguji pengaruhnya terhadap nilai perusahaan. Selain itu, ketiga komponen GCG tersebut juga akan dimoderasi oleh integrated reporting untuk diketahui pengaruh pengungkapan penerapan GCG dalam laporan terpadu (integrated reporting) dalam memperkuat atau memperlemah hubungan langsung antara komponen good corporate governance dengan nilai perusahaan.

\section{Definisi Operasional Variabel Nilai Perusahaan}

Variabel dependen dalam penelitian ini adalah nilai perusahaan seperti yang telah dilakukan oleh (Dewi \& Nugrahanti, 2014), (Sukirni, 2012), (Santoso, 2017) dan (Ardianto \& Ardini, 2018). Nilai perusahaan dalam penelitian ini di ukur dengan menggunakan proksi Market Book Value to Equity (MBVE), dimana rumus yang digunakan untuk menghitung nilai MBVE adalah sebegai berikut:

$$
\begin{aligned}
& \text { NP } \\
& =\frac{\text { Harga Penutupan Saham x Saham Beredar }}{\text { Ekuitas }}
\end{aligned}
$$

\section{Kepemilikan Manajerial}

Kepemilikan manajerial merupakan proporsi kepemilikan saham oleh manajer dalam perusahaan. Kepemilikan manajerial diukur dengan persentase jumlah saham yang dimiliki oleh manajemen. Seperti yang telah dilakukan oleh (Sumanti, 2015) dengan rumus perhitungan sebagai berikut:

\section{KEPMAN}

$=\frac{\text { Jumlah saham yang dimiliki oleh manajemen }}{\text { Jumlah Saham yang Beredar }} \times 100 \%$

\section{Kepemilikan Institusional}

Kepemilikan institusional merupakan persentase kepemilikan saham oleh investor institusional. Rumus perhitungan Kepemilikan Institusional seperti yang telah dilakukan oleh (Susilo et al., 2018) adalah sebagai berikut:

$$
\begin{aligned}
& \text { KEPINS } \\
& =\frac{\text { kepemilikan saham oleh institusi }}{\text { Jumlah Saham yang Beredar }}
\end{aligned}
$$

\section{Komisaris Independen}

Komisaris independen adalah semua komisaris yang tidak memiliki kepentingan bisnis secara substansial di dalam perusahaan. Berdasarkan peraturan OJK jumlah komisaris Independen wajib paling sedikit 30\% (tiga puluh persen) dari seluruh jumlah anggota dewan komisaris. Rumus yang dipergunakan untuk menghitung rasio ini, seperti yang dilakukan (Ardianto \& Ardini, 2018) dalam penelitiannya adalah sebagai berikut:

$$
\begin{aligned}
& \text { KOMIND } \\
& =\frac{\text { Jumlah Komisaris Independen }}{\text { Jumlah Anggota Dewan Komisaris }}
\end{aligned}
$$

\section{Integrated Reporting}

Pengukuran IR menggunakan Content elemen yang terdapat di Rerangka IR. Content elemen terdiri dari Gambaran Organisasi dan Lingkungan Eksternal (empat belas item), Tata Kelola Organisasi (tujuh item), Model Bisnis (Sembilan item), Resiko dan Peluang (tiga item), Strategi dan Alokasi (tujuh item), kinerja (enam item), Prospek Masa Depan (delapan item), dan Dasar Pengungkapan Elemen (tiga item). Setiap indikator yang diungkapkan akan diberi skor 1 dan skor 0 jika tidak diungkapkan.

$$
\mathrm{IR}=\frac{\text { total item }}{57 \text { item }}
$$

\section{Hasil Penelitian dan Pembahasan}

\section{Statistik Deskriptif}

Hasil uji statistik deskriptif digunakan untuk melihat kewajaran dan karakteristik dari masing-masing variabel, dapat dilihat pada tabel berikut:

Tabel 1. Hasil Uji Statistik Deskriptif

\begin{tabular}{ccccc}
\hline Variabel & N & Min & Max & Mean \\
\hline KEPINS & 95 & -4.183 & 0.986 & 0.318 \\
\hline KEPMAN & 95 & -0.381 & 5.509 & -0.306 \\
\hline KOMIND & 95 & -1.916 & 2.963 & -0.290 \\
\hline NP & 95 & -1.006 & 4.936 & -0.298 \\
\hline ROA & 95 & -1.947 & 3.390 & -0.333 \\
\hline DER & 95 & -0.941 & 2.644 & -0.509 \\
\hline IR & 95 & -2.628 & 1.361 & 0.770 \\
\hline
\end{tabular}

Sumber: Data yang diolah 2019

Nilai terendah untuk variabel kepemilikan institusi adalah sebesar -4.183 , nilai tertinggi sebesar 0.986 dan rata-rata 0.318 persen, menunjukkan rata-rata kepemilikan institusi 
dalam perusahaan sebesar 31 persen. Kepemilikan manajemen nilai minimum 0.381 , nilai maksimum 5.509, dan nilai rata-rata sebesar -0.306. Menunjukkan kepemilikan manajemen rata-rata 30 persen. Nilai terendah komisaris independen adalah -1.916 , nilai tertinggi 2.963 , sedangkan rata-rata sebesar 0,290. Menunjukkan jumlah komisaris independen dalam perusahaan berkisar 29 persen.

Nilai rata-rata return on asset sebesar 0.333 , dengan nilai maksimum sebesar 3.390, dan nilai minimum -1.947. Secara rata-rata tingkat pengembalian atas pengelolaan total aset adalah sebesar 33 persen. Perolehan nilai debt equity ratio rata-rata sebesar kurang dari 0.509. sedangkan nilai maksimum yang diperoleh adalah 2.644 dengan nilai minimum yang diperoleh sebesar -0.941. Elemen-elemen integrated reporting nilai rata-rata 0.770 . nilai minimum sebesar -2.628 dengan perolehan nilai maksimum sebesar 1.361 .

\section{Hasil Pengujian Full Model}

Uji signifikansi koefisien jalur dengan menggunakan metode strable3.

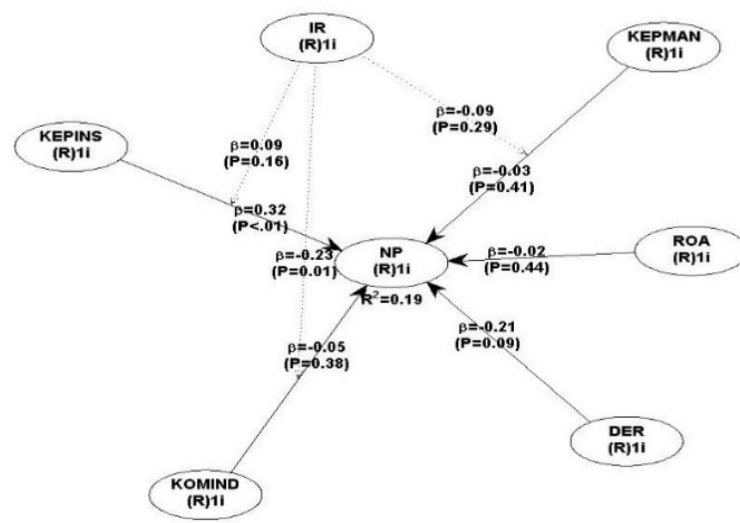

Sumber: Data diolah 2020 (output WarpPLS 6.0)

\section{Gambar 3. Hasil Uji Full Model}

Gambar hasil output di atas menunjukkan persamaan model struktural yang menjelaskan mengenai hubungan antar variabel laten eksogen terhadap variabel laten endogen.

Hasil Uji Determinasi dan Kelayakan Model

Evaluasi determinasi dan kelayakan model dapat dilihat salah satunya dari nilai $R$-Square dan goodness of fit (GoF).
Tabel 2. Hasil Uji R-Square dan Goodness of Fit

\begin{tabular}{ll}
\hline \multicolumn{1}{c}{ Variabel } & Composite Reliability \\
\hline $\begin{array}{l}\text { Average Path } \\
\text { Coefficient }\end{array}$ & $0.129, \mathrm{P}=0.123$ \\
\hline $\begin{array}{l}\text { Average R- } \\
\text { squared }\end{array}$ & $0.190, \mathrm{P}<0.137$ \\
\hline Tenenhaus GoF & $\begin{array}{l}0.436, \text { small }>=0.1, \\
\text { medium }>=0.25, \text { Large } \\
>=0.36\end{array}$ \\
&
\end{tabular}

Sumber: Data diolah 2020

Menurut Ghazali (2011) besaran nilai $R$ Square dapat dikategorikan menjadi 3 bagian yaitu: (1) kategori kuat dengan nilai $R$-Square $>=0.67 ;(2)$ kategori moderate dengan nilai 0.33 $<=R$-Square $<0.67$; (3) kategori lemah dengan nilai $0.19<=R$-Square $>0.33$. Maka besaran nilai ini masuk kategori lemah, hal ini dapat diartikan bahwa variabilitas nilai perusahaan yang dapat dijelaskan oleh kepemilikan manajemen, kepemilikan institusional, dan komisaris independen, serta moderasi integrated reporting hanya sebesar 19\%, sedangkan sisanya sebesar $81 \%$ dijelaskan oleh variabel lain yang tidak diteliti dalam model.

Menurut Tenenhaus (2008) kriteria Goodness of Fit (GOF) adalah sebagai berikut: $\mathrm{GOF}=0.1$ bernilai kecil, $\mathrm{GOF}=0.25$ bernilai sedang, dan GOF $=0.36$ bernilai besar. Hasil pada tabel 4.4 menunjukkan bahwa nilai GOF sebesar 0.436 , hal ini mengindikasikan bahwa besaran nilai GOF adalah besar dan membuktikan bahwa model ini fit dan layak karena lebih dari 0.36 .

\section{Hasil Uji Hipotesis}

Hasil korelasi antar konstruk diukur dengan melihat path coefficients dan tingkat signifikansinya yang kemudian dibandingkan dengan hipotesis satu sampai hipotesis delapan penelitian.

Tabel 3. Hasil Uji Hipotesis

\begin{tabular}{cccc}
\hline Hipotesis & Path & Coefficient & P-value \\
\hline H1 & KEPMAN $\rightarrow$ NP & -0.033 & 0.412 \\
& & & \\
\hline H2 & KEPINS $\rightarrow$ NP & 0.318 & $<0,001$ \\
\hline
\end{tabular}




\begin{tabular}{clcc}
\hline H3 & KOMIND $\rightarrow$ NP & -0.048 & 0.378 \\
\hline H4 & KEPMAN*IR $\rightarrow$ & -0.086 & 0.290 \\
& NP & & \\
& & & \\
\hline H5 & KEPINS*IR $\rightarrow$ & 0.091 & 0.155 \\
& NP & & \\
& & & \\
\hline H6 & KOMIND*IR $\rightarrow$ & -0.228 & 0.015 \\
& NP & & \\
& & & \\
\hline \multirow{4}{*}{ ROA $\rightarrow$ NP } & -0.025 & 0.440 \\
& DER $\rightarrow$ NP & -0.206 & 0.088
\end{tabular}

Sumber: Data diolah 2020 (output WarpPLS 6.0)

Hasil uji hipotesis pertama (H1) pada tabel 4.5 menunjukkan kepemilikan manajerial mendapatkan nilai koefesien sebesar -0.033 dengan tingkat signifikansi (p-value) sebesar 0.412 . Nilai p-value ini lebih besar dari ambang batas nilai signifikansi yang telah ditetapkan yaitu sebesar 0.1, hal ini menunjukkan bahwa hipotesis pertama (H1) ditolak.

Hasil penelitian ini sejalan dengan yang telah dilakukan oleh Ardianto dan Ardini (2018) yang mengungkapkan bahwa "kepemilikan manajerial tidak memberikan pengaruh yang signifikan terhadap nilai perusahaan".

Berdasarkan hasil uji hipotesis kedua (H2) pada tabel 4.5 menunjukkan kepemilikan institusional memperoleh nilai koefesien sebesar 0.318 dengan tingkat signifikansi (pvalue) sebesar $<0.001$. Nilai p-value ini berada dibawah ambang batas nilai signifikansi yang telah ditetapkan yaitu sebesar 0.1, hal ini menunjukkan bahwa hipotesis kedua (H2) diterima. "Kepemilikian institusional akan mendorong manajer selalu menunjukkan kinerja yang baik dihadapan para pemegang saham yang nantinya akan membawa pengaruh terhadap nilai perusahaan" (Susilo et al., 2018).

Berdasarkan hasil uji hipotesis ketiga (H3) pada tabel 4.5 menunjukkan variabel komisaris independen memperoleh nilai koefesien sebesar -0.048 dengan tingkat signifikansi ( $\mathrm{p}$-value) sebesar 0.378. Nilai p-value ini berada diatas ambang batas nilai signifikansi yang telah ditetapkan yaitu sebesar $10 \%$, hal ini menunjukkan bahwa hipotesis ketiga (H3) ditolak. Hasil penelitian ini sejalan dengan penelitian yang dilakukan oleh Badruddien (2017) yang menyatakan bahwa "komisaris independen tidak berpengaruh terhadap nilai perusahaan". Keberadaan komisaris independen dalam perusahaan tidak secara langsung terlibat dalam operasional perusahaan, sehingga masih memungkinkan terjadinya inefisiensi dalam pelaksanaan perusahan.

Berdasarkan hasil uji hipotesis keempat (H4) pada tabel 4.5 menunjukkan variabel kepemilikan manajerial memperoleh nilai koefesien sebesar -0.036 dengan tingkat signifikansi (p-value) sebesar 0.363 setelah dilakukan moderasi dengan menggunakan variabel integrated reporting. Nilai p-value ini berada diatas ambang batas nilai signifikansi yang telah ditetapkan yaitu sebesar $10 \%$, hal ini menunjukkan bahwa hipotesis keempat (H4) ditolak. Keterbaharuan dalam penelitian ini telah menghasilkan bukti yang mendukung atas hipotesis yang pertama bahwa kepemilikan manajerial dalam perusahaan tidak memberikan pengaruh terhadap nilai perusahaan.

Berdasarkan hasil uji hipotesis kelima (H5) pada tabel 4.5 menunjukkan variabel kepemilikan institusional setelah dimoderasi integrated reporting memperoleh nilai koefesien sebesar 0.091 dengan tingkat signifikansi (p-value) sebesar 0.155. Nilai pvalue ini berada diatas ambang batas nilai signifikansi yang telah ditetapkan yaitu sebesar $10 \%$, hal ini menunjukkan bahwa hipotesis kelima (H5) ditolak. sejalan dengan penelitian yang telah dilakukan oleh Susilo et.all (2018) yang menyatakan bahwa "kepemilikan institusional tidak berpengaruh signifikan positif terhadap nilai perusahaan".

Berdasarkan hasil uji hipotesis keenam (H6) pada tabel 4.5 menunjukkan variabel komisaris independen setelah dimoderasi integrated reporting memperoleh nilai koefesien sebesar -0.228 dengan tingkat signifikansi (p-value) sebesar 0.015. Nilai pvalue ini berada dibawah ambang batas nilai signifikansi yang telah ditetapkan yaitu sebesar $10 \%$, hal ini menunjukkan bahwa hipotesis keenam (H6) diterima. Hasil penelitian menunjukkan jumlah rata-rata komisaris independen yang diungkapkan dalam laporan integrated reporting perusahaan sebesar 40 (empat puluh) persen. Hal ini melebihi syarat minimal yang diwajibkan oleh regulasi sebanyak 30 (tiga puluh) persen dari total 
jumlah dewan komisaris.

\section{Kesimpulan, Keterbatasan, dan Implikasi Hasil Penelitian}

Hasil menunjukkan bahwa kepemilikan institusional dalam perusahaan akan meningkatkan pengawasan yang efektif, sehingga akan mendorong manajer selalu berkinerja yang baik dan dapat mengendalikan perilaku oportunistik manajer. Keberadaan komisaris independen tidak secara langsung terlibat dalam operasional perusahaan menyebabkan fungsi pengawasan kurang efektif. Pengungkapan jumlah kepemilikan manajerial dalam laporan yang terintegrasi tidak mampu meningkatkan nilai perusahaan. Pengungkapan kepemilikan institusional dalam laporan yang terintegrasi tidak memberikan pengaruh terhadap nilai perusahaan. Pengungkapan jumlah komisaris independen berpengaruh signifikan terhadap nilai perusahaan.

Keterbatasan dalam penelitian ini, hanya menggunakan 3 (tiga) elemen yang terdapat dalam good corporate governance. Periode penelitian selama 5 (lima) tahun, dan penghitungan skor penyajian elemen integrated reporting melihat realita yang disajikan pada laporan tahunan perusahaan sehingga subyektivitas penilaian akan sangat berpengaruh dalam penghitungan skor di setiap indikator.

Saran untuk penelitian selanjutnya agar dapat menambah jumlah data sampel dan menggunakan metode lain dalam mengukur kualitas integrated reporting. Untuk perusahaan agar meningkatkan kepemilikan oleh institusi dan mengungkapkan keberadaan komisaris independen dalam laporan tahunan.

\section{Daftar Pustaka}

Agustia, D. (2013). Pengaruh faktor good corporate governance, free cash flow, dan leverage terhadap manajemen laba. Jurnal Akuntansi dan Keuangan, 15(1), 27-42.

Ahmar, N. (2007). Analisis Profitabilitas Sebelum dan Sesudah Pemenuhan Corporate Governance pada Perusahaan Manufaktur yang Go Publik di Bursa Efek Jakarta. MAKSI, 7.

Beriwisnu, T. C., \& Priyadi, M. P. (2017). Pengaruh Pertumbuhan Ekonomi,
Industri dan Kinerja Keuangan terhadap Nilai Perusahaan. Jurnal Ilmu dan Riset Akuntansi (JIRA), 6(12).

Agustia, D. (2013). Pengaruh faktor good corporate governance, free cash flow, dan leverage terhadap manajemen laba. Jurnal Akuntansi dan Keuangan, 15(1), 27-42.

Ahmar, N. (2007). Analisis Profitabilitas Sebelum dan Sesudah Pemenuhan Corporate Governance pada Perusahaan Manufaktur yang Go Publik di Bursa Efek Jakarta. MAKSI, 7.

Beriwisnu, T. C., \& Priyadi, M. P. (2017). Pengaruh Pertumbuhan Ekonomi, Industri dan Kinerja Keuangan terhadap Nilai Perusahaan. Jurnal Ilmu dan Riset Akuntansi (JIRA), 6(12).

Dewi, L. C., \& Nugrahanti, Y. W. (2017). Pengaruh Struktur Kepemilikan dan Dewan Komisaris Independen terhadap Nilai Perusahaan (Studi pada Perusahaan Industri Barang Konsumsi di Bei Tahun 2011 - 2013).

Dwi, P. (2011). Analisa Laporan Keuangan Konsep dan Aplikasi, 83. Edisi Ketiga, Yogyakarta: UPP STIM YKPN.

Fiarti, D., \& Chariri, A. (2016). Pengaruh Karakteristik Komite Audit Terhadap Luas Lingkup Integrated Reporting (Doctoral dissertation, Fakultas Ekonomika dan Bisnis).

Hakim, L., \& Priantinah, D. (2018). FaktorFaktor yang Mempengaruhi Nilai Perusahaan pada Perusahaan Manufaktur yang Terdaftar di Bursa Efek Indonesia. Jurnal Profita: Kajian Ilmu Akuntansi, 6(8).

Herawaty, V. (2008). Peran praktek corporate governance sebagai moderating variable dari pengaruh earnings management terhadap nilai perusahaan. Jurnal akuntansi dan keuangan, 10(2), 97-108.

Jensen, M. C., \& Meckling, W. H. (1976). Theory of the firm: Managerial behavior, agency costs and ownership structure. Journal of financial economics, 3(4), 305-360.

Kusuma, R. A. W., \& Priantinah, D. (2018). Pengaruh Pengungkapan Sustainability Report Dan Ukuran Perusahaan Terhadap Nilai Perusahaan Dengan Profitabilitas Sebagai Variabel Pemoderasi Pada Perusahaan Yang Bergabung Di Issi Dan 
Konvensional Periode 20142016. Nominal: Barometer Riset Akuntansi dan Manajemen, 7(2), 91-105.

Linda, W. M. (2017). Pengaruh Profitabilitas, Ukuran Perusahaan Dan Strukturkepemilikan Terhadap Nilai Perusahaan. Jurnal Ilmu dan Riset Akuntansi (JIRA), 6(12).

Novaridha, I. A., Indrawati, N., \& Al-Azhar, L. (2016). Pengaruh Kepemilikan Institusional, Ukuran Perusahaan Dan Profitabilitas Terhadap Elemen-elemen Integrated Reporting (Studi Pada Perusahaan Non-keuangan Yang Listing Di Bei Tahun 2015) (Doctoral dissertation, Riau University).

Rahmadani, F. D., \& Rahayu, S. M. (2017). Pengaruh Good Corporate Governance (GCG), Profitabilitas dan Leverage Terhadap Nilai Perusahaan (Studi Kasus pada Perusahan Perbankan Yang Terdaftar pada BEI Periode 2013-2015). Jurnal Administrasi Bisnis, 52(1), 173182.

Retno, R. D., \& Priantinah, D. (2012). Pengaruh good corporate governance dan pengungkapan corporate social responsibility terhadap nilai perusahaan (studi empiris pada perusahaan yang terdaftar di Bursa Efek Indonesia periode 2007-2010). Nominal: Barometer Riset Akuntansi dan Manajemen, 1(2), 99-103.

Rosiana, G. A. M. E., Juliarsa, G., \& Sari, M. M. R. (2013). Pengaruh pengungkapan CSR terhadap nilai perusahaan dengan profitabilitas sebagai variabel pemoderasi. E-Jurnal Akuntansi, 5(3), 723-728.

Sari, R. A. I., \& Priyadi, M. P. (2016). Pengaruh Leverage, Profitabilitas, Size, Dan Growth Opportunity Terhadap Nilai Perusahaan. Jurnal Ilmu dan Riset Manajemen (JIRM), 5(10).

Sintyawati, N. L. A., \& Dewi, M. R. (2018). Pengaruh Kepemilikan Manajerial, Kepemilikan Institusional dan Leverage terhadap Biaya Keagenan Pada Perusahaan Manufaktur. E-Jurnal Manajemen Universitas Udayana, 7(2).

Setiawan, E., \& Christiawan, Y. J. (2017). Pengaruh Penerapan Corporate Governance Terhadap Nilai Perusahaan dengan Ukuran Perusahaan dan Leverage sebagai Variabel Kontrol. Business
Accounting Review, 5(2), 373-384.

Sukirni, D. (2012). Kepemilikan manajerial, kepemilikan institusional, kebijakan deviden dan kebijakan hutang analisis terhadap nilai perusahaan. Accounting Analysis Journal, 1(2).

Sumanti, J. C., \& Mangantar, M. (2015). Analisis kepemilikan manajerial, kebijakan hutang dan profitabilitas terhadap kebijakan dividen dan nilai perusahaan pada perusahaan manufaktur yang terdaftar di BEI. Jurnal EMBA: Jurnal Riset Ekonomi, Manajemen, Bisnis dan Akuntansi, 3(1).

Susilo, H., Paramita, P. D., \& Andini, R. (2018). Pengaruh Kepemilikan Institusional, Free Cash Flow, Dan Investment Opportunity Set Terhadap Nilai Perusahaan Dengan Kebijakan Hutang Sebagai Variabel Intervening (Studi Kasus Pada Perusahaan Sektor Keuangan Yang Terdaftar Di BEI Periode 20132016). Journal Of Accounting, 4(4).

Tri, A. I., \& Lilis, A. (2018). Pengaruh Kinerja Keuangan Dan Good Governance Terhadap Nilai Perusahaan. Jurnal Ilmu dan Riset Akuntansi (JIRA), 7(1).Bank, A. D. (2016). ASEAN Corporate Governance Scorecard Country Report And Assesment 2014.

Wahyuni, W., Suratno, S., \& Anwar, C. (2017). Pengaruh Intellectual Capital Terhadap Nilai Perusahaan Dengan Free Cash Flow Sebagai Variabel Moderating (Studi Empiris Pada Perusahaan Manufaktur Secondary Sectors di Bursa Efek Indonesia). Jurnal Ilmiah Ilmu Ekonomi (Jurnal Akuntansi, Pajak dan Manajemen), 6(11), 61-73.

Yudiana, I. G. Y., \& Yadnyana, I. K. (2016). Pengaruh Kepemilikan Manajerial, Leverage, Investment Opportunity Set Dan Profitabilitas Pada Kebijakan Dividen Perusahaan Manufaktur. EJurnal Akuntansi, 15(1), 111-141. 